\title{
PENERAPAN PENGGUNAAN MEDIA PEMBELAJARAN VIDEO INTERAKTIF UNTUK MENINGKATKAN MOTIVASI BELAJAR DI SEKOLAH YABES SCHOOL MEDAN
}

\author{
Marice Saragih ${ }^{1}$, Risma Hartati ${ }^{2}$, Ropinus Sidabutar ${ }^{3}$, Rini Wati Sembiring ${ }^{4}$ \\ Amik-Widyaloka, STKIP-Riama, UHKBP Nommensen Pematang Siantar, STKIP Riama \\ Jl.Garu IIb No. 58 Medan, Jl.Antara(Pasar 4,5) Lubuk Pakam III. Deli Serdang, \\ J1. Tritura No.6 Medan \\ Maricesargaih79@gmail.com
}

Received: 2021-02-20, Revised: 2021-03-25, Accepted: 2021-03-30

\begin{abstract}
Abstrak
Video Interaktif adalah metode penceritaan berbasis audio visual yang akan mengajak penonton sebagai pengguna, pemilik dan partisipan aktif terhadap media yang dikemas secara sinematik. Tujuan dari Pengabdian Masyarakat ini adalah untuk memicu dan merangsang belajar siswa sehingga termotivasi dalam mengikuti pelajaran bahasa Inggris dan tentunya juga meningkatkan kemampuan siswa dalam berbahasa Inggris. Melalui kegiatan ini juga dapat menjadi masukan bagi guru bahasa Inggris di SD Yabes School dalam mengajarkan Bahasa Inggris. Kegiatan Pengabdian Masyarakat ini dibagi menjadi lima bagian yaitu kegiatan pre-test, exsplorasi, elaborasi, konfirmasi dan post-test. Pada tahap pre-test para peserta mengerjakan soal yang diberikan tanpa menggunakan video interaktif, pada tahap explorasi nara sumber melakukan brainstorming kepada peserta yang berhubungan dengan video interaktif, setelah melakukan brainstorming narasumber melakukan kegiatan elaborasi, yaitu penjelasan materi tentang penggunaan video interaktif dan menerapkan video interaktif dalam belajar bahasa Inggris, pada tahap konfirmasi peserta diarahkan untuk membentuk kelompok dan mempersentasikan hasil diskusi di depan kelompok lainnya. Pada tahap post-test peserta mengerjakan soal yang berkaitan dengan materi pelatihan dengan hasil terdapat peningkatan nilai post-test meningkat menjadi 76,60 atau 59,26 \% dimana hasil rata-rata pre-test 45.40 sehingga dapat disimpulkan bahwa penerapan video interaktif sangat signifikan dapat meningkatkan pengetahuan bahasa Inggris siswa SD kls V Yabes School
\end{abstract}

Kata Kunci : Video Interaktif, Motivasi Belajar

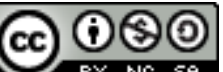

JURNAL WIDYA This work is licensed under a Creative Commons Attribution-NonCommercialShareAlike 4.0 International License. 


\section{PENDAHULUAN}

Yabes School berada di Jl. Krakatau Ujung Gg.Turi Lrg Mawar. Tanjung Mulia Medan.Jumlah dari anak murid SD terdiri dari 170 siswa, pemilik dari sekolah ini sangat perduli dengan pendidikan anak-anak yang ada di Sekolah Yabes School, namun teknik dalam pembelajaran belum variatif sehingga mereka masih sangat kurang termotivasi dalam belajar. Dengan adanya perkembangan jaman saat ini seorang pengajar di tuntut kreatif dalam memberikan pembelajaran baik secara daring maupun secara luring sesuai dengan visi pendidikan nasional.

Visi pendidikan nasional adalah terwujudnya sistem pendidikan sebagai pranata sosial yang kuat dan berwibawa untuk memberdayakan semua warga negara Indonesia berkembang menjadi manusia yang berkualitas sehingga mampu dan proaktif menjawab tantangan zaman yang selalu berubah. Terkait dengan visi tersebut telah ditetapkan beberapa prinsip penyelenggaraan pendidikan, dimana salah satu prinsipnya adalah" pendidikan diselenggarakan sebagai proses pembudayaan dan pemberdayaan peserta didik yang berlangsung sepanjang hayat". Sebagai implikasi dari prinsip ini adalah terjadinya pergeseran paradigma proses pendidikan yaitu paradigma pengajaran ke paradigma pembelajaran. Pembelajaran adalah proses interaksi peserta didik dengan guru dan sumber belajar pada suatu lingkungan belajar

Hal tersebut kemudian diamanatkan dalam Peraturan Pemerintah No. 19 Tahun 2005 tentang Standar Nasional Pendidikan pasal 19 yang berbunyi "Proses pembelajaran pada setiap satuan pendidikan dasar dan menengah harus interaktif, inspiratif, menyenangkan, menantang, dan memotivasi peserta didik untuk berpartisipasi aktif, serta memberikan ruang yang cukup bagi prakarsa, kreativitas, dan kemandirian sesuai dengan bakat, minat, dan perkembangan fisik serta psikologis peserta didik".

Di masa Pandemi sekarang ini seorang guru harus kreatif dalam membuat metode pembelajaran sehingga anak-anak yang diajarkan dapat memahami materi yang disampaikan salah satu contoh bentuk pemberian materi dalam masa pademic ini adalah membuat video interaktif, dengan adanya video interaktif ini anak akan lebih tertarik dalam mengikuti pembelajaran khususnya dalam pembelajaran Bahasa Inggris , namun Kenyataannya pada saat pembelajaran Bahasa Inggris khususnya siswa kelas V SDS Yabes Shool. Peran peserta didik nampak belum secara optimal diperlakukan sebagai subyek didik yang memiliki potensi untuk berkembang secara mandiri. Posisi peserta didik masih dalam situasi dan kondisi belajar yang menempatkan siswa dalam keadaan pasif, aktivitas belajar mengajar masih di dominasi guru dalam menyampaikan informasi yang secara garis besar bahan-bahannya telah tertulis di dalam buku paket. Masalah lainnya banyak siswa yang berbicara sendiri serta adanya beberapa anak yang kurang berkonsentrasi dengan materi yang diajarkan, beberapa siswa dalam mengikuti pelajaran belum sepenuhnya mampu mencerna pembelajaran dengan baik karena dalam menyampaikan materi pembelajaran guru masih cenderung pembelajaran 
teacher centered. Jika seorang guru masih menggunakan metode teacher centered maka peembelajaran pasti kurang di minati siswa, siswa kurang mendapatkan dampak dari pada pembelajaran tersebut

Pengembangan program dilihat dari muatan ranah dan keseimbangannya, mata pelajaran Bahasa Inggris lebih banyak memuat aspek kognitif pada tingkat rendah dan terpusat pada hafalan, sedangkan ranah afektif diakui mengalami kesulitan, baik dalam program maupun dalam melaksanakannya. Akibatnya pelajaran Bahasa Inggris lebih memberikan kesan kepada peserta didik sebagai pelajaran hafalan. Dalam pembelajaran belum menggunakan model pembelajaran yang menarik, guru hanya menggunakan model pembelajaran konvensional saja sehingga tidak ada daya tarik bagi siswa untuk berkonsentrasi pada pelajaran. Kebiasan guru bertindak sebagai pemberi informasi mengembangkan budaya belajar yang menerima dengan pengembangan berpikir pada tingkat hafalan. Peserta didik masih kuat kedudukannya sebagai murid yang memusatkan perhatiannya pada bahan yang disajikan guru. Materi yang disampaikan oleh guru tidak menarik, selain itu guru kurang komunikatif ketika dalam mengajar untuk meningkatkan keaktifan siswa, serta lingkungan belajar kurang kondusif dan kurang tertata rapi, tidak adanya reward dari guru yang mengajar, hal ini mengakibatkan respon siswa masih rendah tidak aktif, kreatif, dan berpikir kritis, dengan kata lain motivasi belajar siswa dalam pembelajaran Bahasa Inggris rendah.

Seorang pendidik harus memiliki teknik bagaimana seorang siswa yang diajar memiliki motivasi yang tinggi terhadap pembelajaran yang akan diberikan, sebab dengan adanya motivasi yang diberikan kepada anak didik hal tersebut membuat mereka bersemangat dalam mengikuti pembelajaran yang kita sampaikan. Tanpa motivasi seseorang tidak dapat belajar. Karena hal itu dapat memberi semangat atau dorongan dan dapat memberi arah dalam belajar. Karena motivasi itu pada dasarnya merupakan keinginan yang ingin dipenuhi (dipuaskan), maka ia muncul/timbul bila dan ada rangsangan, baik karena adanya kebutuhan atau needs maupun interest terhadap sesuatu. Makin tinggi motivasi seseorang untuk meraih apa yang dicita-citakan makin giat orang itu dalam usahanya untuk mencapai cita- cita itu. (Muhammad Ali 1984). Salah satu hal yang sangat berpengaruh terhadap prestasi belajar siswa di sekolah adalah motivasi belajar. Motivasi belajar yang tinggi berkorelasi dengan hasil belajar yang baik, sehingga berbagai upaya dilakukan untuk meningkatkan motivasi belajar siswa di sekolah. Jika motivasi siswa dapat ditingkatkan maka prestasi siswa juga mengalami penurunan. Motivasi belajar merupakan kekuatan mental yang mendorong terjadinya proses belajar. Lemahnya motivasi belajar siswa membuat minat siswa dalam belajar sangat kurang, sehingga mendapatkan hasil yang kurang memuaskan atau mutu hasil belajar rendah. Oleh karena itu motivasi belajar pada diri siswa perlu diperkuat terus menerus. Agar siswa memiliki motivasi belajar yang kuat, pada tempatnya diciptakan suasana belajar yang menggembirakan. Berdasarkan pemikiran di atas, yaitu untuk mengatasi masalah motivasi belajar siswa yang rendah peneliti berusaha mencari solusi yang tepat. Akhirnya ditemukan alternatif pemecahannya yaitu dengan menggunakan Video Interaktif. Video Interaktif adalah metode 
penceritaan berbasis audio visual yang akan mengajak penonton sebagai pengguna, pemilik dan partisipan aktif terhadap media yang dikemas secara sinematik( Cikita Putri, 2019). Materi yang dikemas dalam sebuah video akan memudahkan siswa lebih paham terkait 'pesan yang akan disampaikan. Siswa juga akan lebih tertarik dengan desain yang dibuat sehingga materi akan lebih di ingat oleh siswa. Video interaktif dalam hal ini video untuk memancing siswa pada saat pembelajaran. Siswa akan merespon dari apa yang mereka lihat dan dengar sehingga pesan dari isi materi yang terdapat dalam video akan dikontruksi oleh otak siswa dan menimblkan timbal balik yang berupa pertanyaan-pertanyaan mengenai materi yang terdapat dalam video akan dikontruksi oleh otak siswa sehingga menciptakan interaksi antara siswa dan pengajar. Selain hal tersebut video interktif ini merupakan sebuah video pembelajaran yang berfungsi sebagai pemicu atau rangsangan belajar agar siswa tertarik dengan pembelajaran dan tidak merasa bosan dengan proses pembelajaran dan dengan adanya video interaktif yang diberikan siswa akan lebih cepat memahami materi yang diberikan.

\section{METODE PELAKSANAAN}

Penerapan penggunaan media pembelajaran video interaktif dilaksanakan selama dua hari mulai kegiatan survey lokasi sampai pada kegiatan penerapan yang dilaksanakan pada hari kamis, 13 dan 14 Agustus 2021. Kegiatan ini di ikuti oleh 20 peserta. Metode yang dilakukan dalam kegiatan ini adalah berupa penerapan dengan mengacu pada prosedur dan tahapan-tahapan sebagai berikut:

1. Tahap awal meliputi kegiatan tim dalam melakukan survey lokasi. Pada kegiatan ini tim mendapakan data dan informasi tentang persoalan yang di hadapi mitra serta kebutuhan apa saja yang dapat membantu memecahkan masalah ini. Berdasarkan hasil diskusi disepakati kegitan pelatihan yang akan dilakukan terhadap mitra yang dilaksanakan pada hari kamis tanggal 13 Agustus dari pukul 08.00 sampai dengan 11.00

2. Tahap pelaksanaan penerapan video interaktif dilaksanakan pada hari jumat pukul 08,00 sampai dengan 15.00 meliputi kegiatan : a) pemberian pre-test kepada peserta untuk melihat kemampuan dan pemahaman awal mitra terhadap materi yang akan disampaikan, b) selanjutnya penjelasan tentang konsep dan teori tentang Video interaktif yang disampaikan narasumber dalam bentuk persentase, c) kegiatan Tanya jawab setelah persentase, d) kegiatan simulasi dimana mitra diminta untuk menerapkan materi yang telah diperoleh, e) kegiatan evaluasi, dimana mitra diberi penguatan atas berbagai hal yang berkaitan dengan kegiatan simulasi dan f) pemberian post-test untuk melihat tingkat pemahaman keterserapan materi oleh peserta. Pada akhir sesi kegiatan. Tahap narasumber dan mitra berdiskusi untuk melihat umpan balik dari kegiatan yang dilaksanakan dan tindak lanjut dari kegiatan tersebut dimasa yang akan datang. 


\section{HASIL DAN PEMBAHASAN}

Pada pembahasan ini penulis menjabarkan ada dua hal yang berkaitan dengan pelaksanaan kegiatan pengabdian Masyarakat yang telah dilakuan. Pada tahap analisis kebutuhan mitra diperoleh informasi tentang masalah-masalah yang dihadapi oleh mitra terkait dengan inovasi yang berhubungan dengan alat atau model pembelajaran yang digunakan dalam mengajar dimasa pandemi yaitu dengan menggunakan video interaktif.

Pada tahap pelaksanaan kegiatan, penulis menerapkan tentang penggunaan video interaktif dalam meningkatkan Pengetahuan Bahasa Inggris terhadap Siswa kelas - V SD Yabes School.

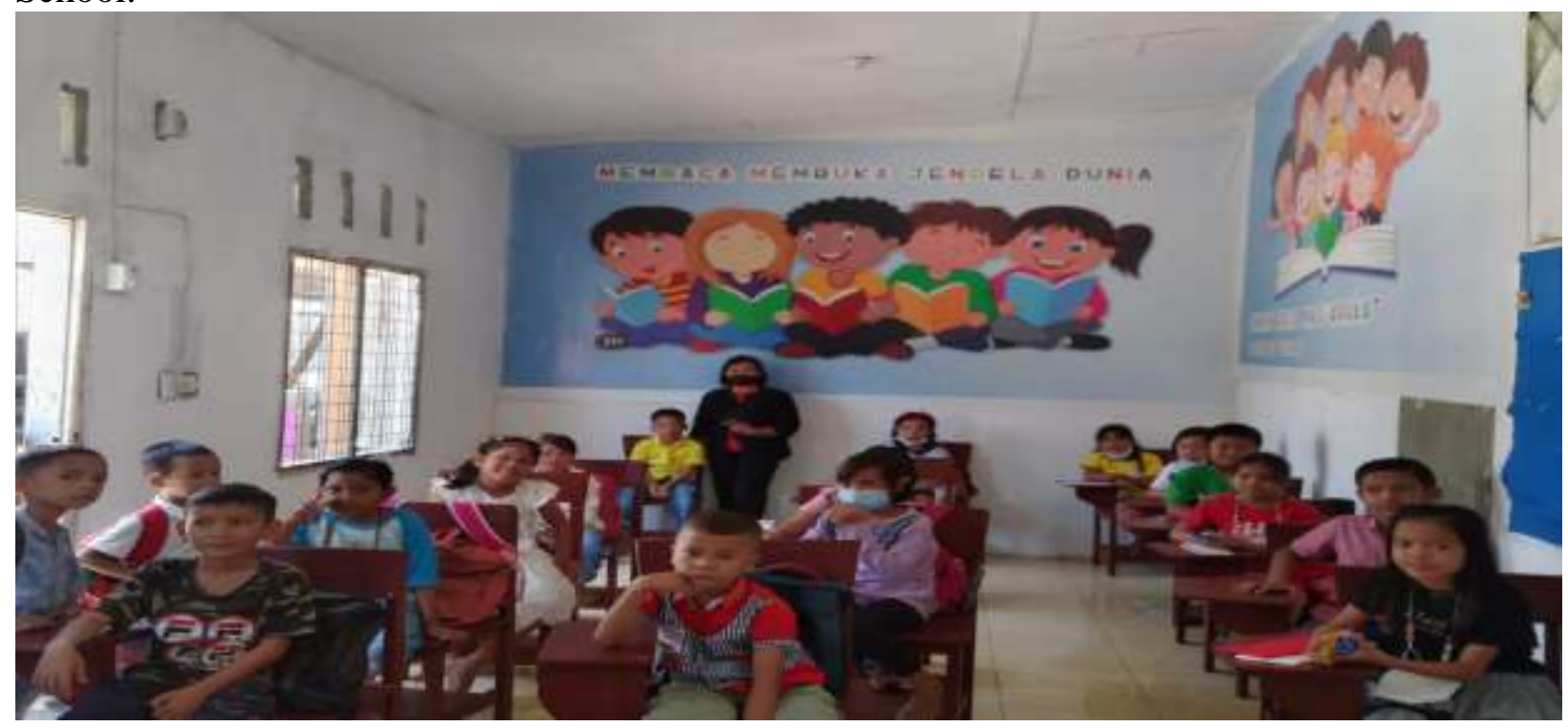

\section{(9) (1) $\Theta(-9)$}

JURNAL WIDYA This work is licensed under a Creative Commons Attribution-NonCommercialShareAlike 4.0 International License. 


\section{Jurnal Widya}

Volume 2, Nomor 1, April 2021: halaman 75-82

https://jurnal.amikwidyaloka.ac.id/index.php/awl

jurnal@amikwidyaloka.ac.id / editor.jurnalwidya@gmail.com
P-ISSN: $2746-5411$

e-ISSN: $x x x x-x x x x$

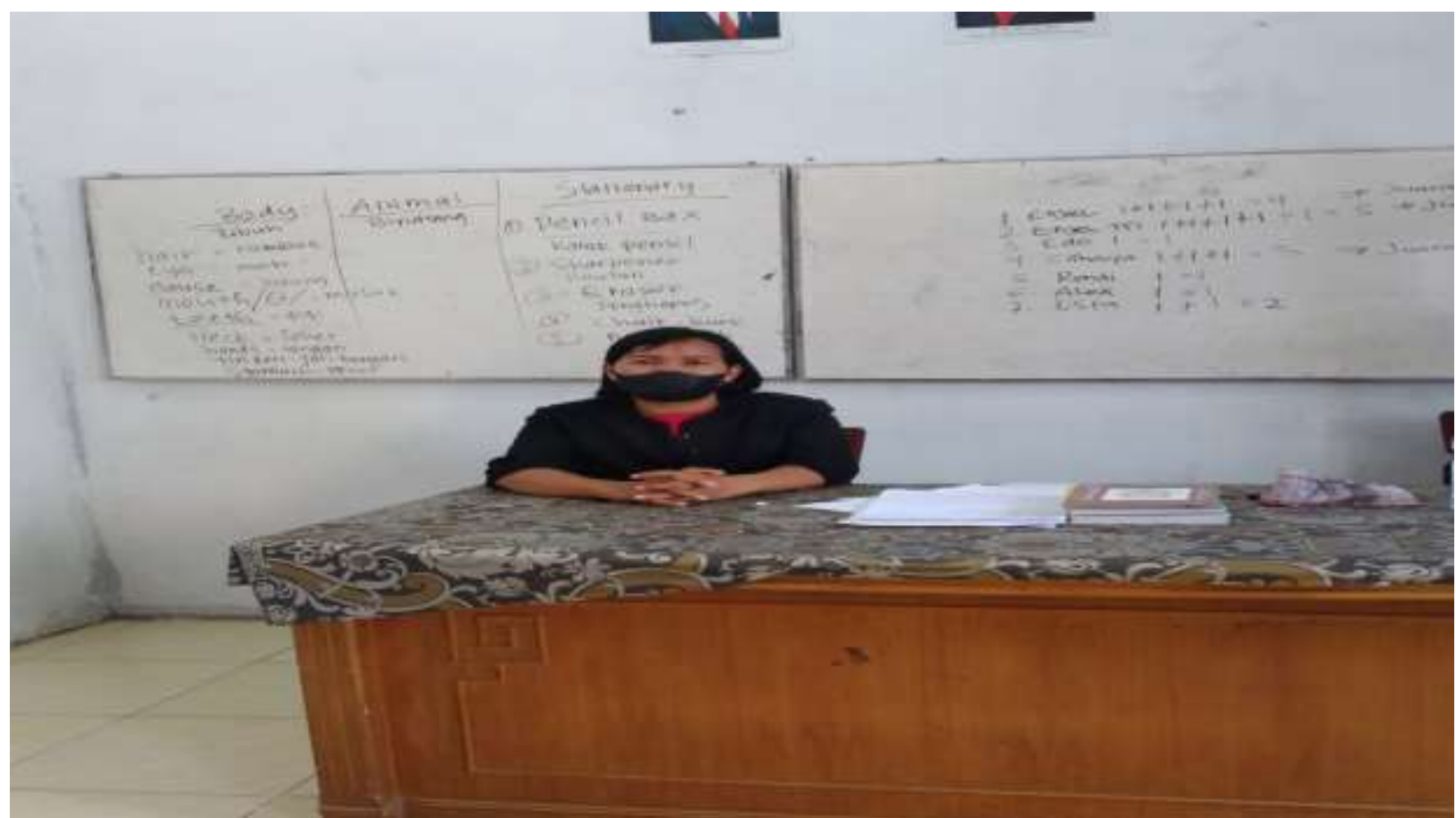

Gambar I . Penulis Menerapkan Penggunaan Video Interaktif di Sekolah Yabes School

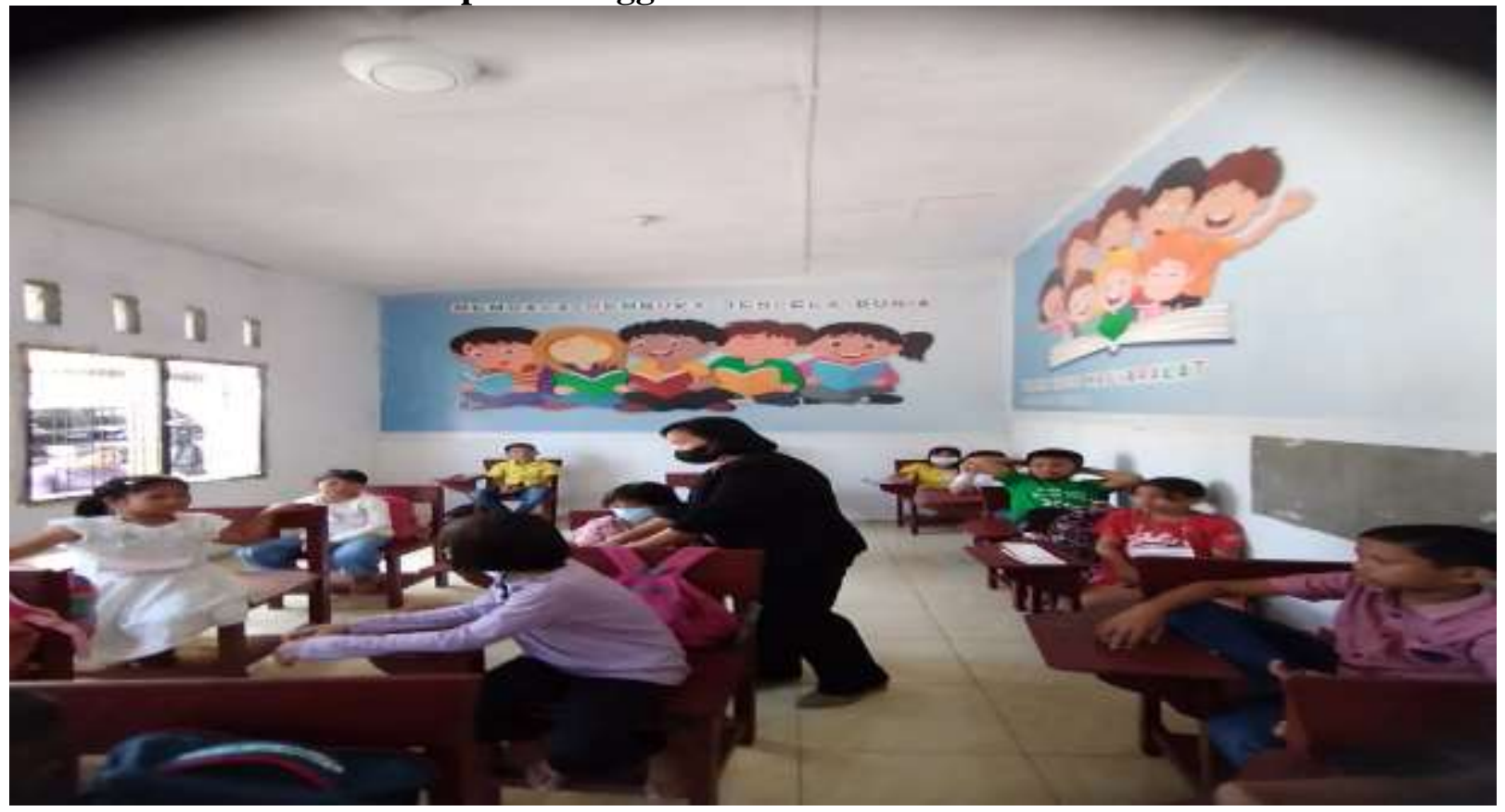

\section{(c) (i) (2)}

JURNAL WIDYA This work is licensed under a Creative Commons Attribution-NonCommercialShareAlike 4.0 International License. 


\section{Gambar 2. Penulis membagikan post test, setelah menggunakan video dan mengumpulkan} Angket

\section{Pelaksanaan Post-Test, Pengisian Kuisioner dan Tanggapan Peserta}

Pada sesi ini seluruh peseta menjawab soal post-test terkait dengan penerapan video interaktif serta mengisi angket kuisioner yang digunakan untuk mengukur pemahaman materi yang disampaikan, dimana hasil dari nilai post- test tersebut akan dibandingakan dengan hasil nilai pre-test yang di laksanakan pada awal kegiatan sebelum diadakan pemaparan materi. Dimana hasil pre-test dibandingkan dengan hasil post-test untuk melihat apakah ada peningkatan pengetahuan bahasa Ingris setelah diadakan penerapan video interaktif. Dan hasil angket kuisioner dipergunakan untuk melihat antusias dan minat peserta terhadap kegiatan pengabdian yang akan digunakan sebagai dasar untuk pengabdian berikutnya. Berikut hasil pre-test dan posttest peserta tentang peningkatan pemahaman siswa setelah siswa menggunakan video interaktif

Tabel.1. Hasil rata-rata Pre-test dan hasil rata-rata Post-test

\begin{tabular}{ccccc}
\hline Jlh.Peserta & $\begin{array}{c}\text { Rata - rata Pre- } \\
\text { test }\end{array}$ & $\begin{array}{c}\text { Rata-rata Post- } \\
\text { test }\end{array}$ & Nilai selisih & \% peningkatan \\
\hline 24 & 45,40 & 76,60 & 31 & 59,26 \\
\hline
\end{tabular}

Berdasarkan tabel diatas dapat dijelaskan bahwa terdapat peningkatan nilai rata-rata pretest dan post-test sebesar 31 atau 59,26 \% setelah peserta menerapkan video interaktif dalam pembelajaran bahasa Inggris maka dapat disimpulkan bahwa penerapan video interaktif dalam pembelajaran bahasa Inggris sangat efektif

Untuk melihat hasil minat dan antusias peserta terhadap kegiatan pengabdian ini, berikut disajikan hasil tanggapan peserta terhadap kegiatan pengabdian seperti tabel 3 berikut.

Tabel 2. Hasil Tanggapan Mitra Terhadap Kegiatan Pengabdian

\begin{tabular}{|c|c|c|c|c|c|c|c|c|c|c|}
\hline \multirow{2}{*}{ Item Pernyataan } & \multicolumn{2}{|c|}{ TS } & \multicolumn{2}{|c|}{ KS } & \multicolumn{2}{|c|}{$\mathbf{S}$} & \multicolumn{2}{|c|}{ SS } & \multicolumn{2}{|c|}{ Total } \\
\hline & $\mathbf{F}$ & $\%$ & $\mathbf{F}$ & $\%$ & $\mathbf{F}$ & $\%$ & $\mathbf{F}$ & $\%$ & $\mathbf{F}$ & $\%$ \\
\hline $\begin{array}{l}\text { Saya sangat tertarik dan ingin tau lebih dalam } \\
\text { tentang materi pengabdian }\end{array}$ & - & - & - & - & 17 & $71 \%$ & 7 & $29 \%$ & 24 & $100 \%$ \\
\hline $\begin{array}{l}\text { Menurut saya pengabdian seperti ini tidak } \\
\text { memberikan manfaat bagi pengembangan } \\
\text { pembelajaran di sekolah saya }\end{array}$ & 21 & $87 \%$ & 3 & $13 \%$ & - & - & - & - & 24 & $100 \%$ \\
\hline $\begin{array}{l}\text { Saya sangat senang karena materi yang } \\
\text { diberikan sangat saya butuhkan dalam } \\
\text { pembelajaan }\end{array}$ & - & - & - & - & 10 & $42 \%$ & 14 & $58 \%$ & 24 & $100 \%$ \\
\hline $\begin{array}{l}\text { Menurut saya materi yang diberikan terlalu sulit } \\
\text { dan tidak bisa saya pahami }\end{array}$ & 13 & $54 \%$ & 11 & $46 \%$ & - & - & - & - & 24 & $100 \%$ \\
\hline $\begin{array}{l}\text { Kegiatan pengabdian dilakukan dengan metode } \\
\text { yang tepat sehingga saya dapat memahami } \\
\text { materi yang disampaikan }\end{array}$ & - & - & - & - & 17 & $71 \%$ & 7 & $29 \%$ & 24 & $100 \%$ \\
\hline Saya merasa terpaksa ikut pengabdia karena & 21 & $87 \%$ & 3 & $13 \%$ & - & - & - & - & 24 & $100 \%$ \\
\hline
\end{tabular}




\begin{tabular}{|c|c|c|c|c|c|c|c|c|c|c|}
\hline \multicolumn{11}{|l|}{$\begin{array}{l}\text { saya merasa sangat awam dengan materi yang } \\
\text { diberikan }\end{array}$} \\
\hline $\begin{array}{l}\text { Saya merasakan manfaat yang signifikan } \\
\text { setelah mengikuti kegiatan pengabdian }\end{array}$ & - & - & - & - & 16 & $66 \%$ & 8 & $34 \%$ & 24 & $100 \%$ \\
\hline $\begin{array}{l}\text { Setelah mengikuti pengabdian ini saya merasa } \\
\text { mendapatkan semangat dan inspirasi baru }\end{array}$ & - & - & - & - & 17 & $70 \%$ & 7 & $30 \%$ & 24 & $100 \%$ \\
\hline $\begin{array}{l}\text { Saya akan mengaplikasikan materi pengabdian } \\
\text { untuk menunjang pembelajaran disekolah }\end{array}$ & - & - & - & - & 17 & $70 \%$ & 7 & $30 \%$ & 24 & $100 \%$ \\
\hline $\begin{array}{l}\text { Saya berharap kembali dilibatkan dalam } \\
\text { kegiatan sejenis diwaktu yang akan datang }\end{array}$ & - & - & - & - & 17 & $70 \%$ & 7 & $30 \%$ & 24 & $100 \%$ \\
\hline
\end{tabular}

Berdasarkan tabel 3 diatas dapat dijelaskan bahwa minat dan antusias peserta cukup tinggi untuk mengikuti pengabdian dibuktikan dengan pada pernyataan manfaat pengabdian, rasa senang mengikuti pengabdian serta inginnya dilibatkan kembali pada kegiatan sejenis diperoleh $70 \%$ peserta meyatakan setuju dan $30 \%$ peserta menyatakan sangat setuju. Dapat disimpulkan bahwa secara keseluruhan peserta merasa senang dan memperoleh manfaat yang signifikan dari fkegiatan pengabdian tersebut serta berharap agar ada tindak lanjut dari kegiatan tersebut.

\section{KESIMPULAN}

Dalam situasi pandemi sekarang ini yang mana pembelajaran diadakan dengan jarak jauh maka seorang guru harus lebih kreatif dalam menyampaikan materi pembelajaran sehingga siswa termotivasi dalam mengikuti pembelajaran. Dengan adanya kegiatan pengabdian masyarakaat ini peserta menyatakan rasa senang mengikuti pengabdian serta inginnya dilibatkan kembali pada kegiatan sejenis ini, hal ini dapat dilihat dari angket yang disebarkan diperoleh $70 \%$ peserta meyatakan setuju dan 30\% peserta menyatakan sangat setuju. Dari hasil post-test peserta terdapat peningkatan nilai post-test meningkat menjadi 76,60 atau 59,26\% dimana hasil ratarata pre-test 45.40 dan selisih antara hasil pre-test dan post-post test adalah 31 dengan demikian dapat disimpulkan bahwa penerapan video interaktif sangat signifikan dapat meningkatkan pengetahuan bahasa Inggris siswa SD Kls V Yabes School

\section{DAFTAR PUSTAKA}

[1] Ali, Mohammad ( 1984). Strategi Penelitian Pendidikan . Bandung : Angkasa [2] Agustania, Anindita. ( 2014) Pengembangan Video Pembelajaran Pada Mata Pelajaran Promosi Dinasmis di SMK Negeri 1. Skripsi. Diakses 26 April 2019

[3] Arsyad, Azhar (2003) Media Pembelajaran. Jakarta : Raja Grafindo Persada

[4] Cikita Putri (2019). Video Interaktif. Jakarta. Diakses 6 April 2019

[5] Kemendikbud, 2013. Peraturan Menteri Pendidikan dan Kebudayaan Rebublik Indonesia No.67 Tahun 2013. Jakarta Kemendikbud

[6] Sadiman ( 1986) . Motivasi dan Belajar. Diakses 6 April 2019 